\title{
Community Attachment and Support for Sustainable Tourism Development through the Attitudes of the Local Population: A Case Study in Puerto Plata, Dominican Republic
}

Pablo Cañero Morales

\author{
Ph.D Candidate \\ University of Córdoba, Spain
}

\author{
Francisco Orgaz Agüera, Ph.D. \\ Vice-chancellor of Production and Scientific Research \\ Technological University of Santiago, \\ Dominican Republic \\ Tomás López-Guzmán, Ph.D. \\ Departament of Applied Economics \\ University of Córdoba, Spain \\ Salvador Moral Cuadra, Ph.D. \\ Technological University of Santiago, \\ Dominican Republic
}

Doi: $10.2478 / \mathrm{mjss}-2018-0037$

\section{Abstract}

The globalization that is currently suffering the world is applicable to tourism, where sustainable tourism practices are required and consistent with the environment in which they develop, so that tourism practices made aware of the local population are conformed as an important engine from the social and economic point of view where it is inserted. The objective of this research is to carry out an analysis between the possible relationships between the attachment of the residents to the community as well as the support of the local population to sustainable tourism and the environmental attitudes of the residents. For this purpose, a duly structured questionnaire was used to carry out a descriptive analysis through the statistical program IBM SPSS v.24.0 and an analysis through the technique of structural equations (Structural Equation Modeling) through the program SmartPLS v.3.2.6. (Partial Least Squares). The results obtained establish a positive influence of community attachment on support for sustainable tourism development.

Keywords: Local population, Puerto Plata, Structural Equations, Sustainable tourism development, attitudes

\section{Introduction}

Studies on the support from residents for sustainable tourism have increased in recent years (Sharpley, 2014) due to the importance of the interaction between visitors and the local community. It has been proven that being successful with appropriate tourism sustainability depends on the support that the local population gives to tourism (Pearce, 1998). Sustainability for tourism development depends on stakeholder support in destinations where local actors play key roles throughout the process, from planning to implementation (Sinclair-Maragh \& Gursoy, 2016). 
The attitudes of residents towards tourism can be positive or negative, and can have economic, social, cultural and environmental dimensions (Andereck et al., 2005). Taking this into consideration, many authors have inquired about the impacts that tourism generates in communities (Gursoy \& Rutherfor, 2004; Andereck et al., 2005; Lepp, 2007). Consequently, Lankford (2001) considers that the study of the impacts of tourism must be carried out in the planning and management process of a tourist destination.

Attitudinal studies have focused on the Social Exchange Theory (Gursoy et al., 2002; Andereck et al., 2005) and the evaluation of support for sustainable tourism. This theory refers to the exchange of resources between different parties in which actors exchange valuable objects and benefits and costs are produced among participating stakeholders (Ap, 1992). Due to the emergence of benefits and costs, tourism researchers have devoted great attention to examining the impact of tourism in recent times (Saarinen, 2006).

From a strictly economic point of view, tourism development is an excellent opportunity for the local communities of a destination to improve their well being, although it implies deteriorating the environment (Bestard \& Nadal, 2007). Thus, despite the economic benefits associated with it, the local population also faces environmental problems caused by tourism (Palmer \& Riera, 2003).

Community tourism is one of the most appropriate ways to generate sustainable rural development, generating economic benefits for local communities (Mehmetoglu, 2001), as well as environmental awareness in the population and visitors (Lee, 2011), and new actions to promote the destination's culture (Boo \& Busser, 2005). Thereupon, community tourism has become a new strategy to explore alternatives that generate new economic resources (Lepp, 2007).

The purpose of this study is to analyze the relationship between the residents' attachment to the community, the support from the local population for sustainable tourism, and the environmental attitudes of the residents. After this introduction, this article has been structured in a second section where the theoretical model and hypothesis of the research is presented. The methodology is shown in a third section and, subsequently, the results of the study in a fourth. Conclusions, implications for management, limitations and future lines of research are given in a fifth section. Finally, the bibliographic references used in the article are presented.

\section{Theoretical Model and Research Hypothesis}

According to Kyle et al. (2004), community attachment is a multifaceted psychological process that reflects the affective, cognitive and behavioral domains of a person's attitude. It is a complex construction for evaluating the attitudes of host residents regarding their communities. According to Jackson \& Inbakaran (2006), the factors that influence the attitude of the resident towards the development of tourism can be classified into demographic, personal, social and those related to tourism activity.

Johnston \& Tyrrell (2005) propose a dynamic model of sustainable tourism, in which they illustrate possible conflicts in the sustainable and unsustainable models of tourism. They demonstrate that there is not a single adequate notion of sustainability, and that an excessively strict environmental quality policy or, on the contrary, one that causes excessive environmental degradation can be very difficult to sustain from the perspective of all tourism stakeholders.

According to Kuvan \& Akan (2005), the attitudes of residents towards the impact of tourism on natural areas, such as forests, indicate that local communities have a favorable attitude towards its development. Nevertheless, they also show great concern for the negative effects of tourism, which they do not ascribe to the activity itself nor the tourists, but to the proper decision making of the public actors.

Residents value the fact that tourism helps to preserve natural resources (Andereck \& Nyaupane, 2011) while also promoting a better appearance of the region (Oviedo-García et al., 2008). In other studies, residents acknowledge that tourism causes pollution (Yoon et al., 2001), trash (Andereck et al., 2005) and agglomeration of public facilities (Bestard \& Nadal, 2007).

McGehee \& Andereck (2004) concluded that residents who are not employed in the tourism industry may have negative attitudes regarding the development of tourism activity because they do not know the positive impacts of tourism and, hence, perceive it as something harmful to the environment. 
Nunkoo et al. (2010) found that women were more concerned about the negative impacts caused by tourism activity and its development. These authors associated this result on the idea that women are more likely to care about their families, the community, society in general, and the environment.

The local community will participate in the development of tourism whenever it finds a benefit in the visitor or the tourist activity itself (Allen et al., 1993). Lepp (2007) suggested that encouraging positive attitudes towards the development of tourism leads to behaviors in favor of tourism. On the other hand, Kwon \& Vogt (2010) revealed a positive relationship between the attitudes of residents towards marketing and the development of local tourism products.

Although several studies on the background of local community support for tourism development have been conducted, there is much ambiguity about the relationship between attitudes and the general support from residents (Prayag et al., 2013). According to Moghavvemi et al. (2017), this ambiguity is due to the measurement and the interchangeable use of the terms "attitude" and "support", which makes it difficult for the resident to recognize the difference and the relationship between both. Zsóka et al. (2013) have suggested that environmental education is crucial to improve environmental attitudes.

When there is no support from residents to work on tourism, the chances of a good relationship between local population and tourists are very low (Pearce, 1998). According to Akis et al. (1996), it is of vital interest for local actors to know if there is support from the community towards the development of the activity. In this sense, Crouch \& Ritchie (2000) determined that the hospitality of residents is considered an element of competitiveness for the destination, which means that the local population is an element that can threaten tourism. Considering these results, new development policies in tourist destinations must take into account the attitudes and opinions of the local community towards tourism, because they perceive environmental deterioration in opposition to economic development by tourism (Bestard \& Nadal, 2007).

The lifestyle of the community can influence the continuous development of tourism, generating economical changes (Simpson, 2008), social changes (Lee et al., 2010) and environmental changes (Lee et al., 2010). Therefore, the development of sustainable tourism is difficult without the support and participation of the residents, which at the same time depend on the changes generated by tourism activity in the local community (Nicholas et al., 2009). Residents who have a greater attachment to the community will be more likely to support the development of sustainable tourism (Lee, 2013), although it will depend on the perceived tourism benefits of local residents (Gursoy \& Rutherford, 2004; Nicholas et al., 2009).

From the previous literature, the research model (Figure 1) and the study hypotheses are presented.

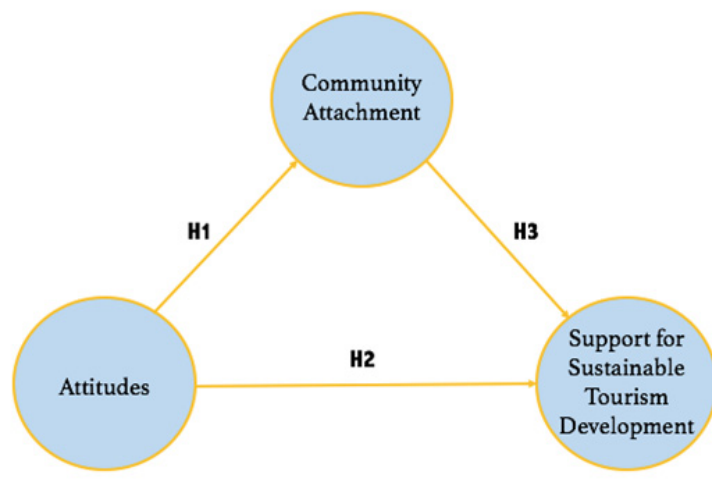

Figure 1. Research model

Source: Own elaboration

The investigation's hypothesis:

- $\mathrm{H} 1$ : the residents' environmental attitudes positively influence the attachment to the 
community.

- $\mathrm{H} 2$ : the residents' environmental attitudes positively influence the support for sustainable tourism development.

- H3: the residents' attachment to the community positively influences the support for sustainable tourism development.

\section{Research Methodology}

\subsection{Sector subject of the study and description of the simple}

Tourist activity generates an important wealth for the host community which, in developing communities, is a very important tool to improve the conditions of the local population. This study focuses on residents who live in the province of Puerto Plata, a geographic region located in the Dominican Republic where important tourism resources are found. This has consolidated tourism in this area as one of the main economic sectors for tourism in this province, offering, above all, sun and beach tourism, nature tourism, ecotourism activity and sports tourism (surfing and windsurfing). Thus, there are tourist activities related to nature, culture and history, as well as leisure. Therefore, it is important to learn about the support from residents towards the sustainable development of tourism, their attachment to the destination of Puerto Plata, and the environmental attitudes they have towards tourism.

According to the National Statistics Office of the Dominican Republic (ONE, 2017), the sample of this research is composed of 133,830 inhabitants. This figure refers exclusively to the rural population, which has been selected against the total population of the province of Puerto Plata so that, when calculating the sample size, the sampling error is minimized. The minimum sample size was set at 473 surveys. The fieldwork was developed from February to May 2014 and 576 valid questionnaires were obtained, thus exceeding the minimum number of instruments to apply, and generating a sampling error of $4.1 \%$ and a confidence level of $95 \%$.

\subsection{Questionnaire design}

To fulfill the objective of the study, a questionnaire was designed. In order to guarantee the validity of the instrument, the formulation of the items was based on some selected from previous researches (Nicholas et al., 2009; Gursoy et al., 2009; Byrd et al., 2009; Gursoy et al., 2010; Lee, 2013).

Once the questionnaire was designed, a process was followed to adjust the items and scales taking into account the errors that may appear during the survey stage and at the time of the data analysis. This process consisted of two phases: The first consisted of the analysis of the items proposed for each section by a researcher specialized in tourism. The second stage consisted of the reviewing of the resulting questionnaire by a statistician. This way, the validity of the items was checked twice. Then, an exact translation of the proposed items was made by a translator from original English to Spanish to minimize the respondents' error when answering, trying to respect the language in terms of meaning, nuances and connotations. Also, a pre-test was carried out for 21 Tourism and Hotel Business Administration students from the Santiago University of Technology (UTESA), located in the province of Puerto Plata of the Dominican Republic.

The designed measuring instrument was structured in four sections: The first section examined the resident's environmental attitudes towards tourism. The second section examined the resident's support towards the development of sustainable tourism. The third section evaluated the resident's attachment to the destination. The fourth section tried to analyze the sociodemographic profile of the people surveyed. The first, second and third sections measured the ratings with a 5point Likert Scale, in which number 1 was equal to "strongly disagree" and 5 refered to "strongly agree", and 3 was interpreted as indifferent. Finally, the sociodemographic profile was analyzed with closed-ended questions concerning the different characteristics of the individual. In short, the questionnaire contained 25 items that evaluated the model proposed in the previous section. 


\subsection{Description of the analysis techniques used}

Once all the questionnaires were received, the information was transferred to Microsoft Excel 2010. Then the IBM SPSS v. 24 and the Smart-PLS software package were used (structural equation technique) in order to analyze them statistically.

Through the statistical program IBM SPSS v. 24, the reliability, descriptive and mean analysis of the questionnaire items were performed. Regarding the structural equation method PLS (Partial Least Squares), it is framed within the Structural Equation Models (SEM), which have become one of the most important recent developments of multivariate analysis, extending among the social sciences (Fornell, 1982).

The main reason to use PLS is to know if the theoretical concepts are correctly measured through the observed variables. To do this, validity and reliability are analyzed. These properties are essential when measuring attitudes, predispositions or emotional responses, which are highly subjective, so that the measurements made cannot be reproduced exactly since the same results are not always obtained using the same instrument. Although the measurement and structural parameters are estimated at the same time, a PLS model is analyzed and interpreted in two stages (Barclay et al., 1995): (1) the evaluation of the reliability and validity of the measurement model, and (2) the evaluation of the structural model. This sequence ensures that valid and reliable measurements are obtained before attempting to draw conclusions regarding the relationships between the composites that relate the hypotheses of this research.

\section{Study Results}

The results of the investigation have been divided into three parts: First, the data on the sociodemographic profile of the sample studied is presented. Secondly, the evaluation of the reliability and validity of the measurement model is shown. Finally, the evaluation of the structural model is carried out.

\subsection{Sociodemographic profile of the sample}

$54.3 \%$ of the respondents were men and $45.7 \%$ of them were women. Most of the questionnaires were answered by the age groups of $35-44,26-34$ and 18-25 years. In terms of household size, $41.3 \%$ live in a three-member household and $41 \%$ in four-member households. Although there are more respondents employed (28.5\%), many do not have jobs (27.6\%)". 90.3\% of respondents do not work in tourism. Table 1 shows the sociodemographic data of the analyzed sample.

Table 1. Sociodemographic profile of the sample

\begin{tabular}{|lr|r|c|}
\hline \multicolumn{1}{|c|}{ Variable } & Categories & Cumulative Frequency & Percentage \\
\hline Gender $(n=576)$ & Man & 313 & \\
& Woman & 263 & 54.3 \\
\hline Age $(n=576)$ & {$[18-25]$} & 120 & 45.7 \\
& {$[26-34]$} & 125 & 20.8 \\
& {$[35-44]$} & 194 & 21.7 \\
& {$[45-54]$} & 69 & 33.7 \\
& {$[55-64]$} & 48 & 12.0 \\
& 65 or more & 20 & 8.3 \\
& & & 3.5 \\
\hline Home size $(n=576)$ & 2 & 0.3 \\
& Individual & 33 & 5.7 \\
& 2 members & 238 & 41.3 \\
& 3 members & 236 & 41.0 \\
& 4 members & 67 & 11.6 \\
\hline
\end{tabular}




\begin{tabular}{|r|c|c|c|}
\hline Variable & Categories & Cumulative Frequency & Percentage \\
\hline Work activity $(n=576) \quad$ Student & 105 & 18.2 \\
& Self-employed & 70 & 12.2 \\
Employed & 164 & 28.5 \\
Unemployed & 159 & 27.6 \\
Retired & 30 & 5.2 \\
Housewife & 48 & 8.3 \\
\hline Works in tourism (n=576) Yes & 56 & 9.7 \\
& No & 520 & 90.3 \\
\hline
\end{tabular}

Source: Own elaboration

\subsection{Evaluation of the measurement model and the reliability of the composites}

The analysis of the different relationships of theoretical nature, which are duly measured by the observable variables, as well as the reliability of the different indicators or items that make up the composites of the model, are carried out according to the measurement model. (CastellanosVerdugo et al., 2016).

Mode B composites (attitudes) can be observed in Table 2, which is measured through the weights, and not the factor loadings as it will be observed in relation to the mode $A$ composites (Chin, 1998b). These weights indicate the relative importance of the mode B items or indicators in the formation of their composite (Orgaz-Agüera, 2014). As said by various authors (Mathieson et al., 2001; Diamantopoulos and Winklhofer, 2011) possible multicollinearity in the mode B composites exist. This makes the usage of the the variance inflation factor test (VIF) necessary to verify the existence or not of this problem. Thus, previous authors point out that VIF values higher than 5 would suppose potential problems of collinearity, although Roberts \& Thatcher (2009) propose an even lower limit, establishing that VIF values higher than 3.3 would indicate problems of multicollinearity. Henseler et al. (2016) establish an even stricter limit, placing VIF values above 1 as potentially susceptible to multicollinearity problems. For this study, the criterion of Roberts \& Thatcher (2009) was chosen. Table 2 shows that none of the values exceeds 3.3 , so multicollinearity does not affect this study.

Table 2 also shows the mode A composites: attachment to the community and support of sustainable tourism development. These are measured through factorial loads (Cepeda \& Roldán, 2004) which are above the minimum threshold of 0.707 . Other authors indicate that this threshold should not be so rigid during initial stages, thus accepting a lower threshold (Barclay et al., 1995; Chin, 1998b). Nevertheless, these factorial loads can never be below 0.4 (Hair et al., 2012) -in this case, they would be eliminated from the model. A criterion of rigidity was adopted in this research, thus eliminating those observable variables with factor loadings less than 0.707 , which were presented in a total of 9 items. Accordingly, the initial model of 25 items was reduced to 16 . On the other hand, the reliability of the composites was measured by Cronbach's alpha and the composite reliability (Werts et al., 1974). Barclay et al. (1995) emphasize the use of composite reliability over Cronbach's alpha, because it is not influenced by the number of indicators or items that the scale to analyze could have (Fornell \& Larcker, 1981). Chin (1998a) points out that these reliability measures for the composites are only applicable to those formed as mode A, therefore, it is not applicable to the mode B composites. For a composite to have composite reliability, it must be placed in a value higher than 0.80 (Nunnally, 1978). This requirement is attained by both mode $A$ composites that are part of the model. In turn, convergent validity measures the degree by which all indicators try to measure the same composite (Cepeda \& Roldán, 2004), implying that said set of observable variables presents a single composite of an underlying character (Henseler et al., 2009). This convergent validity is quantified by the Average Variance Extracted (AVE), which determines the amount of variance a composite obtains from its observable variables (Cepeda \& Roldán, 2004). It must be above 0.50 (Fornell \& Larcker, 1981), implying that more than $50 \%$ of the variance of the composite is due to its indicators or observable variables. 
Table 2. Reliability of composites and observable variables

\begin{tabular}{|c|c|c|c|c|c|c|c|}
\hline Item & $\begin{array}{c}\text { Cronbach } \\
\text { Alpha }\end{array}$ & $\begin{array}{l}\text { Composite } \\
\text { Reliability }\end{array}$ & $\begin{array}{l}\text { Average } \\
\text { Variance } \\
\text { Extracted }\end{array}$ & Loads & Commonality & Weights & VIF \\
\hline $\begin{array}{l}\text { Attitudes (Mode B } \\
\text { composite) }\end{array}$ & $n / a^{1}$ & $n / a$ & $\mathrm{n} / \mathrm{a}$ & & & & \\
\hline $\begin{array}{l}\text { Tourism harms the } \\
\text { environment and the } \\
\text { landscape }\end{array}$ & & & & & & 0.098 & 1.257 \\
\hline $\begin{array}{l}\text { Tourism modifies local } \\
\text { ecosystems }\end{array}$ & & & & & & 0.958 & 1.940 \\
\hline \begin{tabular}{|l} 
Tourism increases \\
environmental pollution
\end{tabular} & & & & & & 0.197 & 2.055 \\
\hline $\begin{array}{l}\text { The creation of tourist } \\
\text { infrastructures changes the } \\
\text { environment }\end{array}$ & & & & & & -0.006 & 1.985 \\
\hline $\begin{array}{l}\text { Tourism has caused } \\
\text { agglomerations on beaches, } \\
\text { parks, routes and other } \\
\text { spaces }\end{array}$ & & & & & & -0.196 & 2.201 \\
\hline $\begin{array}{l}\text { Tourism reduces the habitat } \\
\text { available for endemic fauna } \\
\text { and flora }\end{array}$ & & & & & & -0.316 & 2.018 \\
\hline $\begin{array}{l}\text { Support for sustainable } \\
\text { tourism development (Mode } \\
\text { A composite) }\end{array}$ & 0.688 & 0.859 & 0.754 & & & & \\
\hline $\begin{array}{l}\text { Tourism improves the } \\
\text { promotion of conservation } \\
\text { and environmental education }\end{array}$ & & & & 0.804 & 0.646 & & \\
\hline $\begin{array}{l}\text { Tourism generates the } \\
\text { creation of new tourist } \\
\text { attractions }\end{array}$ & & & & 0.928 & 0.861 & & \\
\hline $\begin{array}{l}\begin{array}{l}\text { Community Attachment } \\
\text { (Mode A composite) }\end{array} \\
\end{array}$ & 0.659 & 0.813 & 0.592 & & & & \\
\hline $\begin{array}{l}\text { I feel satisfied with Puerto } \\
\text { Plata }\end{array}$ & & & & 0.717 & 0.514 & & \\
\hline $\begin{array}{l}\text { Cultural and natural diversity } \\
\text { must be valued and protected }\end{array}$ & & & & 0.785 & 0.616 & & \\
\hline $\begin{array}{l}\text { Greater areas of public space } \\
\text { must be protected }\end{array}$ & & & & 0.803 & 0.645 & & \\
\hline
\end{tabular}

Source: Own elaboration

The discriminant validity shows to what extent a composite is different from other composites present in the model (Cepeda \& Roldán, 2004). This validity shows two different measures: the Fornell criterion and the Heterotrait-Monotrait ratio (HTMT), which is considered more demanding than the first one (Henseler et al., 2016). For the existence of discriminant validity through the Fornell criterion, the existing correlation between each of the composite must be less than the square root of the AVE (Barclay et al., 1995). On the other hand, the Heterotrait-Monotrait ratio must have values between composites lower than 0.90 (Gold et al., 2001; Teo et al., 2008) or 0.85 (Clark \& Watson, 1995; Kline, 2011). In the case of this study, as shown in Table 3, existence of discriminant validity fulfilled for both criteria is observed. 
Table 3: Discriminant validity (Fornell criterion / Heterotrait-Monotrait ratio)

\begin{tabular}{|c|c|c|c|c|c|c|}
\hline $\begin{array}{l}\text { Fornell } \\
\text { Criterion }\end{array}$ & Attitudes & $\begin{array}{l}\text { Community } \\
\text { attachment }\end{array}$ & $\begin{array}{c}\text { Support for } \\
\text { sustainable } \\
\text { tourism } \\
\text { development }\end{array}$ & HT-MT Ratio & $\begin{array}{l}\text { Community } \\
\text { attachment }\end{array}$ & $\begin{array}{c}\text { Support for } \\
\text { sustainable } \\
\text { tourism } \\
\text { development }\end{array}$ \\
\hline Attitudes & $n / a$ & - & - & $\begin{array}{l}\text { Community } \\
\text { Attachment }\end{array}$ & & \\
\hline $\begin{array}{l}\text { Community } \\
\text { attachment }\end{array}$ & 0.210 & 0.769 & - & \begin{tabular}{|c|} 
Support for \\
sustainable \\
tourism \\
development
\end{tabular} & 0.466 & \\
\hline $\begin{array}{l}\text { Support for } \\
\text { sustainable } \\
\text { tourism } \\
\text { development }\end{array}$ & 0.123 & 0.332 & 0.868 & & & \\
\hline
\end{tabular}

Source: Own elaboration

The evaluation of the measurement model is optimal, as reflected in the data collected in Tables 2 and 3 , so that the analysis of the structural model could be continued.

\subsection{Evaluation of the structural model}

By means of the Bootstrapping technique (5000 subsamples), the stability of the estimates was examined, and the normality of the sample did not have to be met, unlike the cases addressed through CB-SEM (Hair et al., 2017). The nonparametric character of the sample was carried out through a hypothesis test based on confidence intervals (Barroso et al., 2010), with a significance of 0.05 . The hypothesis contrast based on confidence intervals is presented in Table 4. Thus, Hypothesis $\mathrm{H1}$, which indicated a positive influence of attitudes on community attachment, has not been supported, as has the Hypothesis $\mathrm{H} 2$, which indicated that attitudes have a positive influence on support for sustainable tourism development. On the other hand, Hypothesis $\mathrm{H} 3$ has been supported, stating the positive influence the attachment to the community has on the support for sustainable tourism development.

Table 4: Statistical Hypothesis

\begin{tabular}{|c|c|c|c|c|}
\hline \multirow[b]{2}{*}{ Hypothesis } & \multirow[t]{2}{*}{ Coefficient } & \multicolumn{2}{|c|}{ Intervals } & \multirow[b]{2}{*}{ Supported? } \\
\hline & & $2.5 \%$ & $97.5 \%$ & \\
\hline H1: ATTITUDES $\rightarrow$ COMMUNITY ATTACHMENT & 0.210 & 0.278 & 0.307 & No \\
\hline $\begin{array}{l}\text { H2: ATTITUDES } \rightarrow \text { SUPPORT FOR SUSTAINABLE TOURISM } \\
\text { DEVELOPMENT }\end{array}$ & 0.056 & $\overline{-}$ & 0.156 & No \\
\hline $\begin{array}{l}\text { H3: COMMUNITY ATTACHMENT } \rightarrow \text { SUPPORT FOR } \\
\text { SUSTAINABLE TOURISM DEVELOPMENT }\end{array}$ & 0.320 & 0.208 & 0.422 & Yes \\
\hline
\end{tabular}

Source: Own elaboration

Table 5 shows the explained variance, understood as the amount of variance that each exogenous variable explains in relation to the endogenous variables. In relation to the predictive relevance of the composites, they are measured through the Q2 of Stone-Geisser (Geisser, 1975), having to present values higher than 0 for the model to present predictive relevance (Henseler et al., 2009). This occurs in all cases of this research (Q2 Community attachment $=0.020$; Q2 Support for sustainable tourism development $=0.071$ ). Based on the data shown in Table 5 , attitudes explain $4.4 \%$ of the variance of attachment to the community, and $0.688 \%$ of the variance of support for 
sustainable tourism development, while community attachment explains $10.62 \%$ of the variance of support for sustainable tourism development.

Table 5. Explained variance (effect on endogenous variables)

\begin{tabular}{|c|c|c|c|c|c|}
\hline & $\mathbf{R}^{2}$ & $\mathbf{Q}^{2}$ & Coefficient & Correlation & $\begin{array}{c}\text { Explained variance } \\
(\%)\end{array}$ \\
\hline $\begin{array}{l}\text { Community attachment } \\
\text { H1: attitudes }\end{array}$ & 0.044 & 0.020 & 0.210 & 0.210 & $4.4 \%$ \\
\hline $\begin{array}{l}\text { Support for sustainable tourism development } \\
\text { H2: Attitudes } \\
\text { H3: Community attachment }\end{array}$ & 0.113 & 0.071 & $\begin{array}{l}0.056 \\
0.320\end{array}$ & $\begin{array}{l}0.123 \\
0.332 \\
\end{array}$ & $\begin{array}{l}0.688 \% \\
10.62 \%\end{array}$ \\
\hline
\end{tabular}

Source: Own elaboration

Figure 2 shows the data related to the final model.

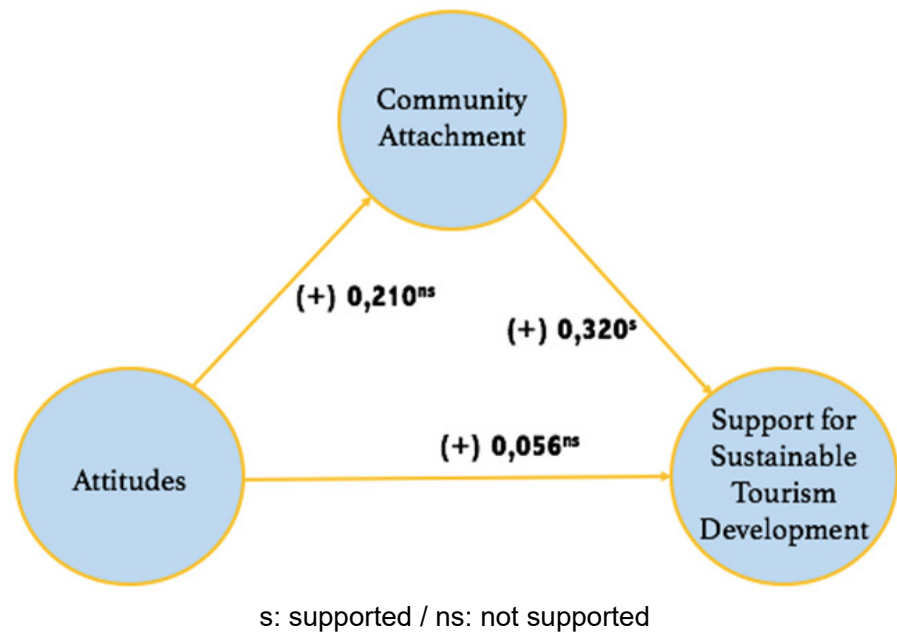

Figure 2. Structural model.

s: supported / ns: not supported

Source: Own elaboration

\section{Conclusions, Implications for Management, Limitations and Future Research Lines}

Tourism is presented as an innocuous activity that generates large movements of people, causing, irremediably, important impacts on the destination. The study of these impacts has been a topic of importance for the scientific community and is seen in the numerous investigations that have analyzed the impacts of tourism in the territory. In this sense, the objective of this research has been to analyze the relationship between the residents' attachment to the community, the support of sustainable tourism from the local population and the environmental attitudes of the residents. The fieldwork of this research has been carried out in the province of Puerto Plata, which is the main tourist area in the north of the Dominican Republic. As in the rest of the country, this destination has experienced significant growth rates, both in tourist arrivals and in average annual occupancy of hotel establishments, due to the diversification of tourism: in addition to sun and beach tourism, complementary activities related to culture, sports and nature are offered.

Among the main conclusions, it has been observed that there is a positive influence from the local population and the attachment to the community towards support for development of sustainable tourism, even though Gursoy et al. (2002) had established that community attachment has no effect on residents' support for sustainable tourism. On the other hand, no positive 
relationship has been found between attitudes on attachment to the community and between attitudes and support for sustainable tourism development. Therefore, the greatest influence obtained for sustainable tourism development of a destination depends on the attachment that residents have to their community and, above all, on whether tourism generates benefits in their community. According to Byrd (2007), the perceived impact is a predictor of residents' support for the sustainable tourism development of a community.

The results can be useful for the Public Administration, so that a greater number of grants and resources can be allocated to promote and maintain community tourism policies in especially vulnerable areas. They should take into greater consideration the important benefits that can be generated if community tourism policies are developed, considering previous analysis and studies based on empirics. Accordingly, they can manage tourism in a way that improves the quality of life and opportunities of the residents of the local communities and promotes local culture. Managers of rural communities must continue to bet on the sustainable development of tourism and especially on the development of community tourism, since it generates jobs for the local community, as well as improves the conservation of resources, cultural identities, environment and boosts the economy. Also, local managers must continue contributing to the social development of the community through actions of corporate social responsibility that improve the quality of life of the population, as has been done with the creation of aqueducts, the donation of ambulances or the education of the residents.

Regarding the limitations of this research, it is considered that a longitudinal study carried out in different moments would have been, without a doubt, much more appropriate and attractive according to the objectives of this study. Also, the research is presented solely from the point of view of the residents, making it difficult to disseminate the discoveries to other stakeholder groups relevant to tourism in Puerto Plata. Thus, the data collected refers to a geographical area (Puerto Plata) and a single sector and category (tourism). Regarding future lines of research, it is worth evaluating a similar longitudinal investigation that considers time to be able to evaluate how perceptions and attitudes vary in respect to the destination, as well as to observe other variables. Also, it would be interesting to replicate the questionnaire to other local stakeholders. Finally, it would be interesting to develop this study in other areas of the country, in order to compare the results between similar and even different destinations.

\section{References}

Akis, S., Peristianis, N., \& Warner, J. (1996). Residents' attitudes to tourism development: the case of Cyprus. Tourism management, 17(7), 481-494.

Allen, L. R.., Hafer, H. R.., Long, P. T., \& Perdue, R. R. (1993). Rural residents' attitudes toward recreation and tourism development. Journal of travel research, 31(4), 27-33.

Andereck, K. L., \& Nyaupane, G. P. (2011). Exploring the nature of tourism and quality of life perceptions among residents. Journal of Travel Research, 50(3), 248-260.

Andereck, K. L., Valentine, K. M., Knopf, R. C., \& Vogt, C. A. (2005). Residents' perceptions of community tourism impacts. Annals of tourism research, 32(4), 1056-1076.

Ap, J. (1992). Residents' perceptions on tourism impacts. Annals of tourism Research, 19(4), 665-690.

Barclay, D., Higgins, C., \& Thompson, R. (1995). The partial least squares (PLS) approach to causal modeling: Personal computer adoption and use as an illustration. Technology studies, 2(2), 285-309.

Barroso, C., Cepeda, G., \& Roldán, J.L. (2010). Applying maximum likelihood and PLS on different sample sizes: studies on Servqual model and employee behavior model. In: Esposito Vinzi, V., Chin, W.W., Henseler, J., Wang, H. (Eds.), Handbook of Partial Least Squares: Concepts, Methods and Applications (pp. 427-447). Berlin: Springer.

Bestard, A. B., \& Nadal, J. R. (2007). Modelling environmental attitudes toward tourism. Tourism Management, 28(3), 688-695.

Boo, S., \& Busser, J. A. (2005). Impact analysis of a tourism festival on tourists destination images. Event Management, 9(4), 223-237.

Byrd, E. T., Bosley, H. E., \& Dronberger, M. G. (2009). Comparisons of stakeholder perceptions of tourism impacts in rural eastern North Carolina. Tourism Management, 30(5), 693-703. 
Castellanos-Verdugo, M., Vega-Vázquez, M., Oviedo-García, M. Á., \& Orgaz-Agüera, F. (2016). The relevance of psychological factors in the ecotourist experience satisfaction through ecotourist site perceived value. Journal of Cleaner Production, 124, 226-235.

Cepeda, G. \& Roldán, J.L. (2004). Aplicando la Técnica PLS en la Administración de Empresas. En: XIV Congreso ACEDE: Conocimiento y Competitividad, septiembre, Murcia.

Chin, W. W. (1998a). Issues and opinion on structural equation modelling. Management Information Systems Quarterly, 22(1), 1-8.

Chin, W.W. (1998b). The Partial Least Squares Approach to Structural Equation Modeling. In: Marcoulides, G.A. (Ed.), Modern Methods for Business Research (pp. 295-336). Mahwah, NJ: Lawrence Erlbaum Associates Publisher.

Clark, L.A., \& Watson, D. (1995). Constructing validity: basic issues in objective scale development. Psychological Assessment, 7(3), 309-319.

Crouch, G. I., \& Ritchie, J. B. (2000). The competitive destination: A sustainability perspective. Tourism management, 21(1), 1-7.

Diamantopoulos, A., \& Winklhofer, H.M. (2001). Index construction with formative indicators: An alternative to scale development. Journal of Marketing Research, 38, 269-277.

Fornell, C. (1982). A second generation of multivariate analysis: An overview. In Fornell C. (Ed.). A Second Generation of Multivariate Analysis (pp. 1-21). New York, EEUU: Praeger Publishers.

Fornell, C., \& Larcker, D.F. (1981). Evaluating structural equations models with unobservable variables and measurement error. Journal of Marketing Research, 18, 39-50.

Geisser, S. (1975). The predictive simple reuse method with applications. Journal of the American Statistical Association, 70(350), 320-328.

Gold, A. H., Malhotra, A., \& Segars, A. H. (2001). Knowledge management: an organizational capabilities perspective. Journal of Management Information Systems, 18(1), 185-214.

Gursoy, D., Chi, C. G., \& Dyer, P. (2009). An examination of locals' attitudes. Annals of Tourism Research, 36(4), 723-726.

Gursoy, D., Chi, C. G., \& Dyer, P. (2010). Locals' attitudes toward mass and alternative tourism: The case of Sunshine Coast, Australia. Journal of Travel Research, 49(3), 381-394.

Gursoy, D., Jurowski, C., \& Uysal, M. (2002). Resident attitudes: A structural modeling approach. Annals of tourism research, 29(1), 79-105.

Gursoy, D., \& Rutherford, D. G. (2004). Host attitudes toward tourism: An improved structural model. Annals of tourism Research, 31(3), 495-516.

Hair, J.F., Sarstedt, M., Ringle, C.M. \& Mena, J.A. (2012). An assessment of the use of partial least squares structural equation modeling in marketing research. Journal of the Acad. Mark. Sci., 40(3), 414-433.

Hair, J.F., Hult, G.T., Ringle, C. M., \& Sarstedt, M. (2017). A primer on partial least squares structural equation modeling (PLS-SEM). Thousand Oak: Sage.

Henseler, J., Ringle, C.M. \& Sinkovics, R.R. (2009). The use of Partial Least Squares Path Modeling in International Marketing. Advances in International Marketing, 20, 277-319.

Henseler, J., Hubona, G., \& Ray, P.A. (2016). Using PLS path modeling in new technology research: updated guidelines. IMDS, 116(1), 2-20.

Jackson, M. S., \& Inbakaran, R. J. (2006). Evaluating residents' attitudes and intentions to act towards tourism development in regional Victoria, Australia. International Journal of Tourism Research, 8(5), 355-366.

Johnston, R. J., \& Tyrrell, T. J. (2005). A dynamic model of sustainable tourism. Journal of Travel Research, 44(2), 124-134.

Kline, R.B. (2011). Principles and practice of structural equation modelling. (3rd Edition). New York: Guildford Press.

Kuvan, Y., \& Akan, P. (2005). Residents' attitudes toward general and forest-related impacts of tourism: the case of Belek, Antalya. Tourism management, 26(5), 691-706.

Kwon, J., \& Vogt, C. A. (2010). Identifying the role of cognitive, affective, and behavioral components in understanding residents' attitudes toward place marketing. Journal of Travel Research, 49(4), 423-435.

Kyle, G. T., Mowen, A. J., \& Tarrant, M. (2004). Linking place preferences with place meaning: An examination of the relationship between place motivation and place attachment. Journal of environmental psychology, 24(4), 439-454.

Lankford, S. V. (2001). A comment concerning developing and testing a tourism impact scale. Journal of Travel Research, 39(3), 315-316.

Lee, T. H. (2011). How recreation involvement, place attachment and conservation commitment affect environmentally responsible behavior. Journal of Sustainable Tourism, 19(7), 895-915.

Lee, T. H. (2013). Influence analysis of community resident support for sustainable tourism development. Tourism management, 34, 37-46.

Lee, C. K., Kang, S. K., Long, P., \& Reisinger, Y. (2010). Residents' perceptions of casino impacts: A comparative study. Tourism Management, 31(2), 189-201. 
Lepp, A. (2007). Residents' attitudes towards tourism in Bigodi village, Uganda. Tourism management, 28(3), 876-885.

Mathieson, K., Peacock, E., \& Chin, W.W., (2001): Extending the technology acceptance model: the influence of perceived user resources. Data Base Adv. Inf. Syst., 32 (3), 86-112.

McGehee, N. G., \& Andereck, K. L. (2004). Factors predicting rural residents' support of tourism. Journal of Travel research, 43(2), 131-140.

Mehmetoglu, M. (2001). Economic scale of community-run festivals: A case study. Event Management, 7(2), 93-102.

Moghavvemi, S., Woosnam, K. M., Paramanathan, T., Musa, G., \& Hamzah, A. (2017). The effect of residents' personality, emotional solidarity, and community commitment on support for tourism development. Tourism Management, 63, 242-254.

Nicholas, L. N., Thapa, B., \& Ko, Y. J. (2009). Residents' perspectives of a world heritage site: The pitons management area, St. Lucia. Annals of Tourism Research, 36(3), 390-412.

ONE (2015). Perfiles estadísticos provinciales de la provincia de Puerto Plata. Santo Domingo, República Dominicana: Oficina Nacional de Estadística de la República Dominicana.

Orgaz Agüera, F. (2014). Análisis del ecoturismo en República Dominicana: Desarrollo Sostenible. El caso del Monumento Natural Saltos de la Damajagua (Tesis Doctoral), Sevilla. Universidad de Sevilla.

Oviedo-García, M., Castellanos-Verdugo, M., \& Martin-Ruiz, D. (2008). Gaining residents' support for tourism and planning. International journal of tourism research, 10(2), 95-109.

Palmer, T., \& Riera, A. (2003). Tourism and environmental taxes. With special reference to the "Balearic ecotax". Tourism Management, 24(6), 665-674.

Pearce, P.L. (1998). The relationship between residents and tourists: The research literatura and management directions. In W.F. Theobald (Ed.), Global tourism (2nd ed., pp.129-149). Oxford, UK: ButterworthHeinemann.

Prayag, G., Hosany, S., Nunkoo, R., \& Alders, T. (2013). London residents' support for the 2012 Olympic Games: The mediating effect of overall attitude. Tourism Management, 36, 629-640.

Roberts, N. \& Thatcher, J. B. (2009). Conceptualizing and testing formative constructs: Tutorial and annoted example. The Data Base for Advances in Information Systems, 40(3), 9-39.

Saarinen, J. (2006). Traditions of Sustainability in Tourism Studies. Annals of Tourism Research, 38, 1121-40.

Sharpley, R. (2014). Host perceptions of tourism: A review of the research. Tourism Management, 42, 37-49.

Simpson, M. C. (2008). Community benefit tourism initiatives-A conceptual oxymoron?. Tourism Management, 29(1), 1-18.

Sinclair-Maragh, G., \& Gursoy, D. (2016). A conceptual model of residents' support for tourism development in developing countries. Tourism Planning \& Development, 13(1), 1-22.

Teo, T.S.H., Srivastava, S.C., \& Jiang, L. (2008). Trust and electronic government success: An empirical study. Journal of Management Information Systems, 25(3), 99-132.

Werts, C.E., Linn, R.L. \& Jöreskog, K.G. (1974). Interclass reliability estimates: testing structural assumptions. Educational and Psychological Measurement, 34, 25-33.

Yoon, Y., Gursoy, D., \& Chen, J. S. (2001). Validating a tourism development theory with structural equation modeling. Tourism management, 22(4), 363-372.

Zsóka, Á., Szerényi, Z. M., Széchy, A., \& Kocsis, T. (2013). Greening due to environmental education? Environmental knowledge, attitudes, consumer behavior and everyday pro-environmental activities of Hungarian high school and university students. Journal of Cleaner Production, 48, 126-138. 